\title{
Online Assessment System for Certificates of Proficiency Revalidation
}

\author{
Vidya Selasdini, Antoni Arif Priadi \\ Sekolah Tinggi Ilmu Pelayaran \\ Jl.Marunda Makmur Cilincing Jakarta Utara 14150, 021-88991618 \\ e-mail: selasdini.vidya@gmail.com
}

\begin{abstract}
The seafarer must attend and follow the assessment again as the final stage of the revalidation process. Many Seafarers might feel difficult with this condition because they actually have not enough time to do it. The problem studied in this research is how validation and assessment can be carried out online to the Certificate of Proficiency participants in Sekolah Tinggi Ilmu Pelayaran (Maritime Higher Education). This research aims to make a validation model and assessment carried out to the Certificate of Proficiency participants online to accelerate maritime certification services. This type of research is quantitative. From the research results, it is concluded that the implementation of online BST certificate revalidation at STIP can be carried out by still paying attention to the requirements starting from the registration process, evaluation to the issuance of the revalidation certificate. The legality of a certificate revalidation carried out online is the same and legal as a revalidation certificate that is carried out regularly. The entire series of processes are carried out by applicable SOP's and does not provide any loopholes for fraudulent acts.
\end{abstract}

Keywords: revalidation, certificates of proficiency, online

\section{Introduction}

Indonesia is one of the world's largest countries with the largest seafaring population after the Philippines, China, Russia, and Ukraine. The population of seafarers worldwide serving commercial ships on international routes is estimated at 1,647,500 seafarers, of which 774,000 are officers, and 873,500 are ratings. The Philippines is the largest seafarer supplier for rating positions, followed by China, Indonesia, the Russian Federation, and Ukraine. Meanwhile, China is the largest ship officer's supplier, followed by the Philippines, India, Indonesia, and the Russian Federation. (international chamber of shipping-2019)

Global demand for seafarers is estimated at 1,545,000, with a position required of around 790,500 Officers and 754,500 for Ratings. This shows that the number of officers on board has increased by around $24.1 \%$, while the demand for an aboard rating has increased by about $1.0 \%$.

In 2005, BIMCO / ISF reported a deficit of 10,000 maritime officers for global ships (BIMCO / ISF, 2005). In 2010, the number increased to 13,000 (BIMCO / ISF, 2010). Drewry (2015) reports that there is a deficit of 19,000 for Officer posts on ships. A year later, BIMCO / ISF (2015) indicated a shortage of as many as 16,500 ship officers globally. This number is expected to increase to 147,500 by 2025 .

Indonesia itself currently has Seafarers spread both on ships with foreign flags and ships with Indonesian flags. The cabotage principle's effect provides its benefits for the

This paper is presented in The $4^{\text {th }}$ International Conference on Maritime Education and Training

October $8^{\text {th }}$,2020, Makassar, Indonesia 
Seafarer's community in Indonesia because this principle's birth indirectly provides opportunities for Indonesian citizens to work on ships. The high interest of the Indonesian people to work in the maritime world is also encouraged by Presidential Instruction No. 9 of 2016 concerning the revitalization of Vocational High Schools in the context of improving the quality and competitiveness of Indonesian Human Resources.

Most of the Seafarers who have taken the training then work on commercial ships, only a few works on state ships or fishing boats. President Jokowi, through his vision of building a maritime toll road, indirectly gives the mandate to implementers of maritime education and training to provide the best service and availability for Indonesian Seafarers.

Talking about service to seafarers is unique because seafarers' conditions and work environment are not as common as general jobs. For example, a work contract that ranges from three to twelve months on board. During the contract period, the Seafarers are not allowed to return home. The work location, which is in the middle of the sea with extreme weather that always accompanies the seafarers to work, becomes a separate consideration for the Company in providing compensation/salary.

A seafarers' rhythm must also adjust to the business flow carried out by shipping companies in the maritime world. There are times when a ship only docked for two hours at the port for loading and unloading and then returned to sail. Alternatively, the ship has to sail from one country to a particular country by crossing different continents.

This condition causes how meaningful a time is for seafarers, especially when they have time on land. As the most extensive marine education and training provider in Indonesia, STIP (Sekolah Tinggi Ilmu Pelayaran), known as Maritime Higher Education, is always committed to providing fast and precise services. Ramsoek (2010) suggests that service quality is an organization's ability to meet or exceed consumer expectations.

One of the services provided by STIP is the revalidation of maritime certificates for Basic Safety Training (BST). Following the STCW Amendment 2010, Table B I / 2 List of Certificates of Documentary Evidence Required Under the STCW Convention, several certificates need to be revalidated, including:

Table 1. List of certificates to be validated

\begin{tabular}{|c|c|c|c|c|}
\hline No & Certificates & Endorsement & Revalidation & Rules \\
\hline 1 & GMDSS Radio Operator & Yes & Yes & $\begin{array}{lr}\mathrm{II} / 1, & \mathrm{II} / 2, \mathrm{II} / 3, \mathrm{III} / 1, \\
\mathrm{III} / 2, \mathrm{III} / 3, \mathrm{III} / 6, \mathrm{IV} / 2, \mathrm{VII} / 2\end{array}$ \\
\hline 2 & $\begin{array}{l}\text { Ratings as Navigational or Engine } \\
\text { room watch }\end{array}$ & NO & NO & $\mathrm{II} / 4, \mathrm{III} / 4, \mathrm{VII} / 2$ \\
\hline 3 & $\begin{array}{l}\text { Ratings as Able seafarer deck, able } \\
\text { seafarer engine atau electro -technical } \\
\text { rating }\end{array}$ & No & No & $\mathrm{II} / 5, \mathrm{III} / 5, \mathrm{III} / 7, \mathrm{VII} / 2$ \\
\hline 4 & $\begin{array}{l}\text { CoP or endorsement CoC for Masters } \\
\text { and Officers on Oil,Chemical or } \\
\text { liquefied gas tankers }\end{array}$ & Yes & Yes & $\mathrm{V} / 1-1, \mathrm{~V} / 1-2$ \\
\hline 5 & $\begin{array}{l}\text { CoP for Ratings on Oil,checmical or } \\
\text { liquefied gas tankers }\end{array}$ & No & No & $\mathrm{V} / 1-1, \mathrm{~V} / 1-2$ \\
\hline 6 & CoP - basic Training & No & Yes & $\mathrm{V} / 1-1$ \\
\hline 7 & $\mathrm{CoP}-\mathrm{SCRB}$, and FRB & No & Yes & $\mathrm{V} / 1-2$ \\
\hline 8 & CoP- AFF & No & Yes & $\mathrm{VI} / 3$ \\
\hline 9 & $\mathrm{CoP}-\mathrm{MFA}$ and MC & No & No & $\mathrm{VI} / 4$ \\
\hline 10 & $\mathrm{CoP}-\mathrm{SSO}$ & No & No & $\mathrm{VI} / 5$ \\
\hline 11 & CoP - SAT or SDSD & No & No & $\mathrm{VI} / 6$ \\
\hline 12 & CoP-Ships Operating in Polar Waters & No & Yes & $\mathrm{V} / 4$ \\
\hline 13 & CoP - Ships Subjects to the IGF Code & No & Yes & $\mathrm{V} / 3$ \\
\hline 14 & $\begin{array}{l}\text { Documentary Evidence - Training } \\
\text { personnel serving on Passange ships }\end{array}$ & No & No & $\mathrm{V} / 2$ \\
\hline
\end{tabular}

This paper is presented in The $4^{\text {th }}$ International Conference on Maritime Education and Training 
The Indonesian government has also shared this regulation through a circular from the Director of Shipping and Maritime Affairs of the Directorate General of Sea Transportation (Number : UM .003 / 2412 / DK-18) concerning the Implementation of the Revalidation of the Maritime Education and Training Program. This is an obligation for all seafarers in Indonesia to always validate or refresh their maritime documents Certificate of Proficiency (COP). The management of maritime documents can only be carried out by Technical Implementing Units / Training Administrators who have obtained permission or approval from the Directorate General of Shipping and Maritime Affairs, Ministry of Transportation. Moreover, Sekolah Tinggi Ilmu Pelayaran (STIP) is one of them. Other Training Administration are spread all over Indonesia, from Aceh to Sorong.

Based on seafarers' conditions and the data mentioned above, it is suitable for seafarers to get fast and precise service. Many of the seafarers who come to STIP come from cities outside Jakarta, such as from the islands of Sumatra, Kalimantan, Sulawesi, even to Papua. The location of the training center that is far from where they live becomes an obstacle and a problem. The large amount of money that must be spent to pay for transportation, housing, and living expenses while in Jakarta is an inevitable burden.

When a seafarer wants to validate his certificate, the Seafarer must attend and re-attend the assessment as the final stage of the revalidation process. Many seafarers might find difficulties in this condition because they have not enough time to do it. They can only revalidate when they have completed the contract on the ship. When they are on board, they cannot do the revalidation. Seeing this condition, the authors are interested in providing a solution to seafarers, especially inefficient time and cost.

Possible solutions that can be offered are a remote validation system to save time and, of course, save costs. However, this method must go through a research test because there are no rules that allow this process to be carried online by utilizing existing technology.

This research will conduct trials on samples or model long-distance maritime certificates provided by STIP based on the explanation above. Some of the problems that are still visible are as follows:

1. Long term period for Seafarer's contract.

2. The work location is in the middle of the sea with extreme weather.

3 . Berthing time at the loading and unloading port.

4. Indonesian seafarers are scattered throughout the archipelago, including areas which are still difficult to reach

5. Locations of several Training Administrator, which are generally only found in big cities in Indonesia.

6. The period of the certificate revalidation issuance procedure.

Of the various problems above, the discussion is carried out by limiting the following:

1. Issuance for only one Certificate of Proficiency, BST revalidation

2. Issuance for BST certificate from STIP

The formulation of the problem in this research s how can validation or assessment be carried out online on participants of the COP revalidation issued by STIP?

This research aims to make a validation model and assessment that can be carried out online on participants of the COP revalidation to accelerate maritime certification services.

The urgency of doing this research is:

1. This research is vital to improving the performance of STIP services for training participants, especially for seafarers who are spread throughout Indonesia.

2. This research can be used as input in deepening customer satisfaction in receiving services from transportation service providers

\section{Research Method}

According to its title, this research will be conducted in Jakarta with the target respondents, including operators and regulators, as well as the Seafarer who took the Basic Safety Training (BST) certificates in STIP. This research was conducted for three months, starting in March 2020.

This paper is presented in The $4^{\text {th }}$ International Conference on Maritime Education and Training 166 
The data collection method is done in 2 ways: literature study to obtain secondary data, while primary data is obtained by asking respondents' opinions through questionnaires. Secondary data is obtained in the form of empirical data from business actors or related agencies and literature studies. The empirical data that will be obtained include visits to training organizers, the performance of skills training services, certificate revalidation activities. Primary data comes directly from informants who are generally participants of skills training, government officials, and other related parties who are in contact with the policy of implementing a remote certificate revalidation system.

Primary data is packaged in the form of a questionnaire or a questionnaire, a data collection technique that is carried out by giving questions in writing to respondents. The questionnaire questions in this study are closed. Besides, interviews were also conducted in order to obtain other supporting input from related stakeholders.

This study's population were all participants in the training for seafarers' skills, especially those who had a Basic Safety Training (BST) certificate at STIP and other stakeholders or related agencies. Sampling was carried out by random sampling, considering that its implementation is relatively easy and is expected to facilitate data processing from several specified samples. The number of samples taken is at least 100 respondents interviewed and guided if there are things that have not been understood in filling out the questionnaire distributed at STIP. Primary data collection will be assisted by several operator colleagues who have previously been briefed.

This research is a descriptive qualitative research design using a survey method (nonexperimental). Descriptive research/research is a type of research that wants to explain or describe something that is described quantitatively. The process is carried out by analyzing existing / actual data and information and collecting respondents' opinions through surveys related to efforts to determine the level of remote revalidation services at STIP Jakarta.

This research's data analysis method is descriptive qualitative to understand the importance of developing a remote revalidation process following the objectives to be achieved. The data analysis steps used are described as follows:

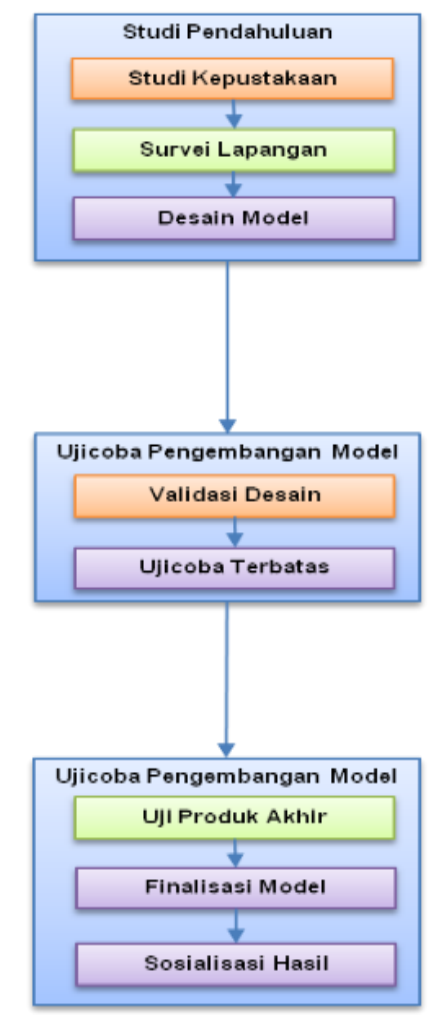

Figure 1. Analisis Process 
The explanation of Figure 1 is as follows:

1. Literature study

A literature study is carried out with several models, namely Distance Assessment, Skype, BST

Revalidation Standard Operational Procedure (SOP), BST Curriculum \& syllabus, BST

Revalidation Registration SOP, SOP Issuance of BST revalidation certificates.

2. Model I Development Trials

Conducted by validating the design and being tested to the limit by surveying the location of the residence of the participants who took part in the BST revalidation ( 2 weeks of taking a questionnaire to the revalidation participants)

3. Trial of Model II Development

This is done by testing the final product, finalizing the selected model, and then socializing the results to related parties.

4. Conclusion Withdrawal

The data is collected and arranged in detail for further analysis and evaluation. It is easy to conclude response to the formulation of the problem set at the beginning of the study.

When a seafarer wants to validate his certificate, the Seafarer must attend and re-attend the assessment as the final stage of the revalidation process. Many seafarers might feel objection to this condition because they have not enough time to do it. They can only revalidate when they have completed the contract on the ship. Seeing this condition, the authors are interested in providing a solution to seafarers, especially in streamlining time and costs. Possible solutions that can be offered are a remote validation system to save time and, of course, save costs. Through a research test, it is hoped that the convenience and validation test system for the application of the remote revalidation system can be used for Indonesian seafarers by utilizing existing technology.

\section{Results and Analysis}

\subsection{Description of Respondents}

This study uses data that is processed from several types of questionnaires. Before conducting this test, we gave questionnaires distributed to several training participants who registered at STIP. Below are the questionnaire results from the respondents regarding the study of the level of service revalidation at STIP.

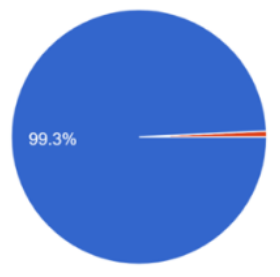

Male

Female

Figure 2 BST Revalidation Participant Gender Diagram

Figure 2 shows the comparison of the number of respondents based on the male or female sex. Most of the respondents were male, as much as $99.3 \%$, while the rest were female as much as $0.7 \%$, this is because the training participants who registered to become seafarers were mostly men.
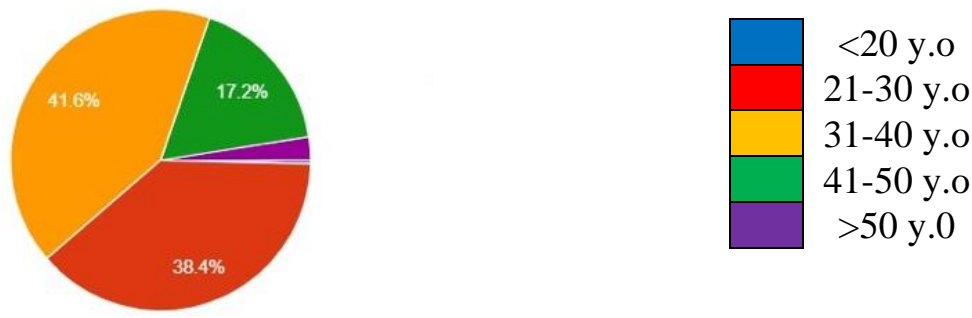

Figure 3 Age Diagram of BST Revalidation Participants

This paper is presented in The $4^{\text {th }}$ International Conference on Maritime Education and Training 
Figure 3 shows a comparison of the respondents' age, which is divided into five age groups. The 31-40 year age group occupied the highest position at $41.6 \%$, followed by the $21-30$ year age group at $38.4 \%$, followed by the $41-50$ year age group at $17.2 \%$. The fourth age group is more than 50 years old, and the last is the age group of fewer than 20 years. The highest average age of respondents is in the productive age for working on ships, while the lowest is under 20 years of age because there are still not many who sail, and some are still attending education and training.
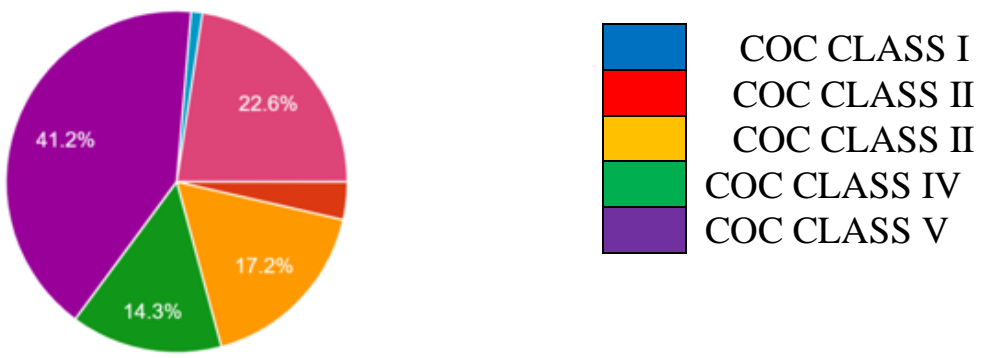

Figure 4 Diagram of BST Revalidation Participants' Maritime Certificate Types

Figure 4 shows the last certificate held by the respondent. The highest position was 41.2\% having ANT / ATT V certificates, then $22.6 \%$ had Able certificates followed by ANT / ATT III and ANT / ATT IV certificates. Respondents who have ANT / ATT certificate class II and class I are in the lowest rank.
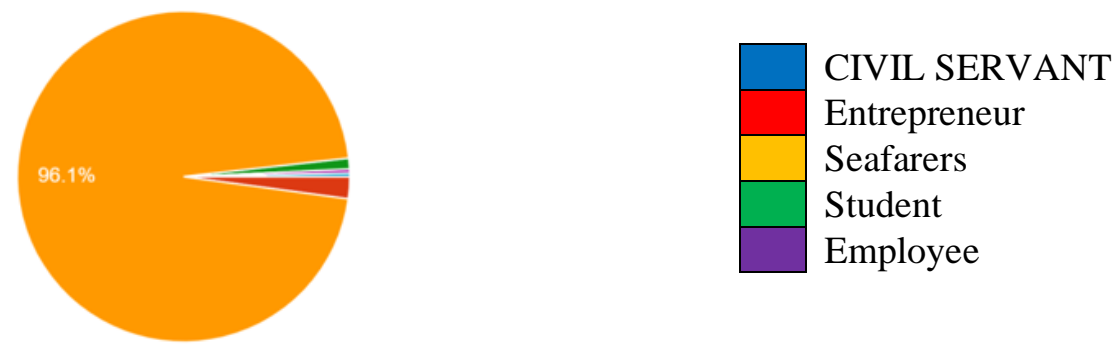

Figure 5 Job Diagram of BST Revalidation Participants

Figure 5 shows the respondent's type of work, and it is evident that most respondents' occupation is seafarers as much as $96.1 \%$. The rest of the respondents' occupations, respectively, are as workers in private/self-employed companies, students/students, and civil servants / TNI / POLRI. Questionnaires were distributed specifically to be distributed to seafarers and training participants who were taking skills training.
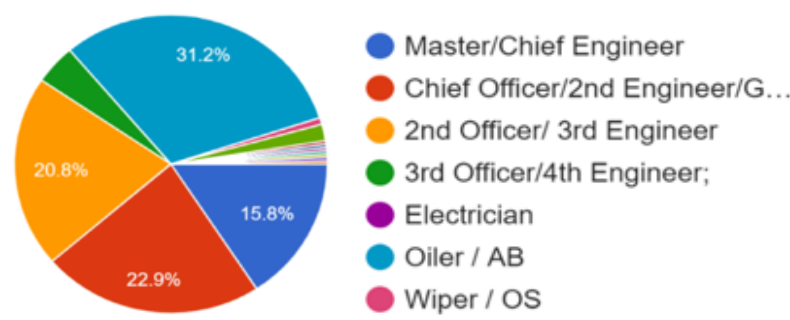

Figure 6 Position diagram of BST Revalidation Participants on board

Figure 6 above shows the respondent's job position on a boat or in a company for

This paper is presented in The $4^{\text {th }}$ International Conference on Maritime Education and Training 169 
those who work on the land. As many as $31.2 \%$ were respondents who held positions as oiler / AB aboard ships followed by Chief Officer / second Engineer positions at 22.9\%, followed by second officer / third engineer positions at $20.8 \%$ and management level positions or Master \& Chief Engineer at $15.8 \%$. Some of the respondents also work as Directors in shipping companies.
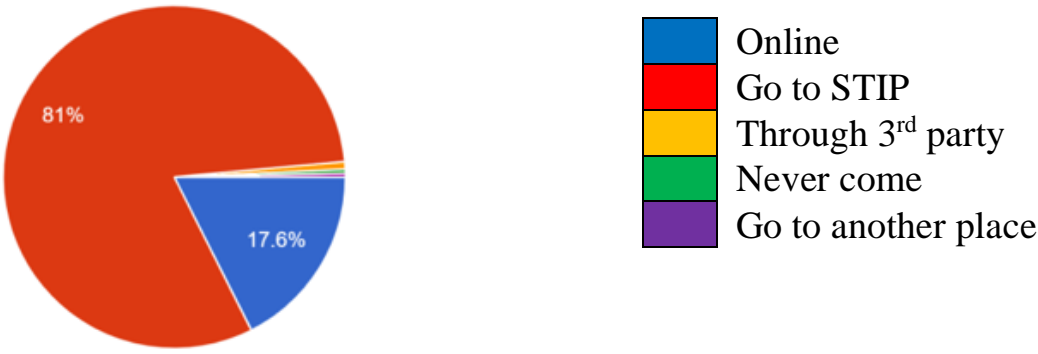

Figure 7 Diagram of How Participants Perform BST Revalidation

Figure 7 shows how the respondents did the revalidation. The choice to come to STIP is the primary choice made by respondents as much as $81 \%$. For those who did not choose to come to STIP, $17.6 \%$ could register online. As is known, STIP currently has provided space for seafarers who wish to register online through the STIP official website. In this way, it is considered effective to reach people outside Java or who are still on the ship.

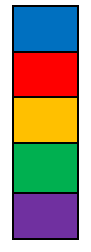

$$
\begin{aligned}
& \text { Jakarta area } \\
& \text { Java island } \\
& \text { Sumatere island } \\
& \text { Kalimantan island } \\
& \text { Sulawesi Island }
\end{aligned}
$$

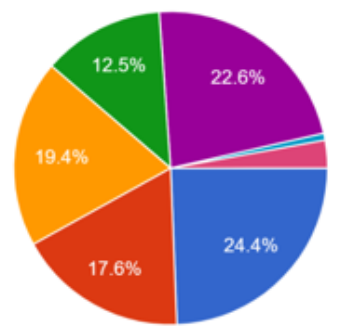

Figure 8 Diagram of Residence Location of BST Revalidation Participants

Figure 8 shows a map of the distribution of the respondents' locations, namely in Jabodetabek (Jakarta, Bogor, Depok, Tangerang, Bekasi) as much as 24.4\%. $22.6 \%$ of seafarers outside Jabodetabek consist of seafarers domiciled in Sulawesi Island as much as $22.6 \%, 19.45$ on Sumatra Island, 17.6\% in West Nusa Tenggara, East Nusa Tenggara and surrounding areas, and $12.5 \%$ Kalimantan island. The protest of people from outside Java to get an education at STIP is very large even though there are actually similar training centers at the Ministry of Transportation in some islands.

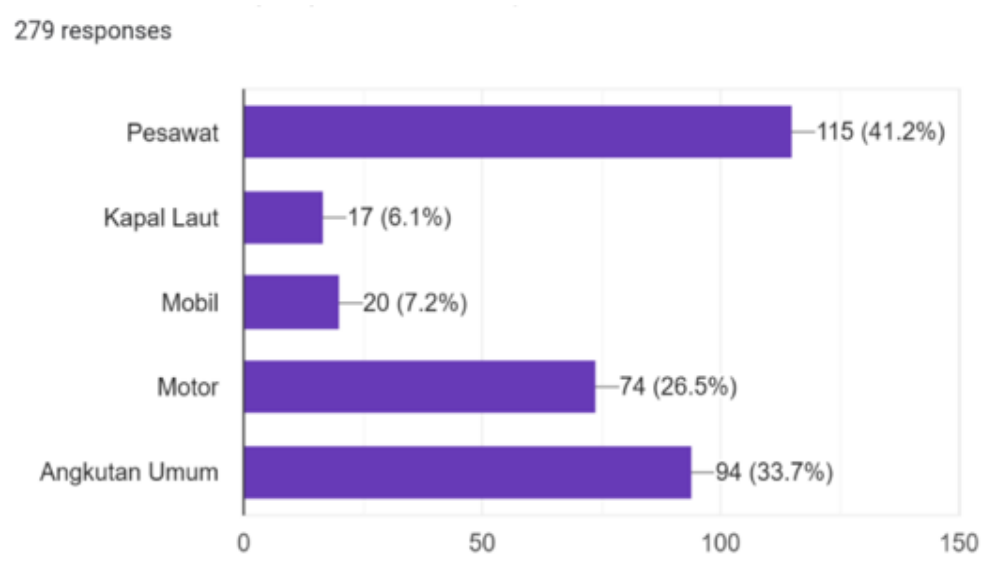

Figure 9 Transportation diagram used by BST to STIP Revalidation Participants

This paper is presented in The $4^{\text {th }}$ International Conference on Maritime Education and Training 
Figure 9 shows the mode or means of transportation used by the respondent to go to STIP. The largest percentage used airplane transportation, which was $41.2 \%$, which means that many of the respondents came from outside Jakarta - then followed by participants who use public transportation such as Trans Jakarta, public transportation, and online transport with a percentage of $33.7 \%$. Participants who may be/live in the Jabodetabek area can come to the STIP by using motorized transportation (26.5\% and car (7.2\%). The smallest percentage of $6.1 \%$ is transportation by ship used by respondents to come to STIP. This condition is generally only for some people who live in difficult areas to reach by land and sea transportation.

279 responses
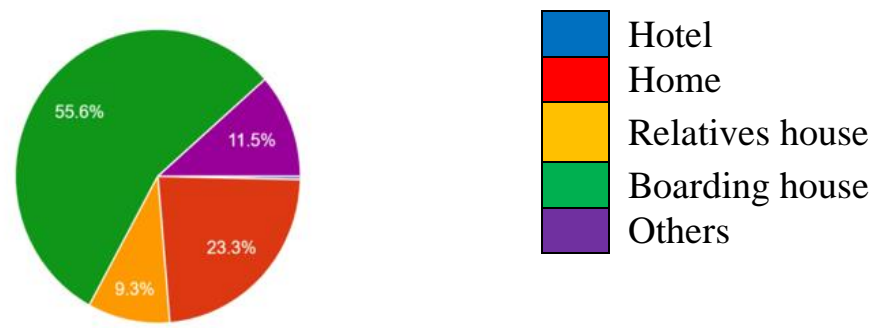

Figure 10 Diagram of Accommodation / Residence of BST Revalidation Participants

Figure 10 shows the accommodation of the participants. As 55,6\% lived in rented houses, they lived in a mess, relatives, and their own house.

\subsection{The percentage of indicators in each dimension}

A. Safety services

1. Safety facilities for training participants from their residence location to STIP
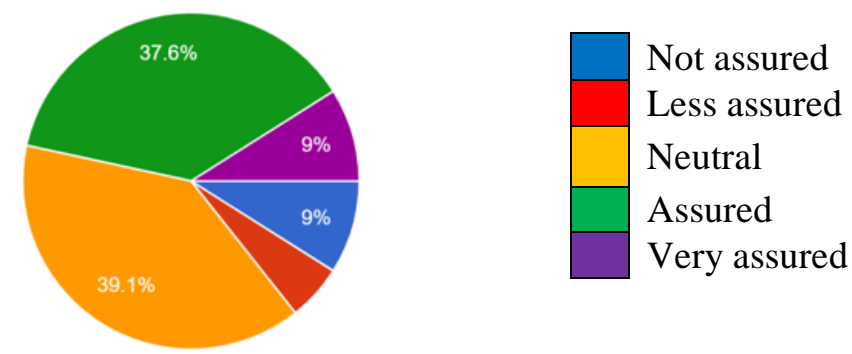

Figure 11. Safety diagram for training participants from their residence location to STIP

Figure 11 shows the safety facilities for training participants from their residence location to STIP. $39.1 \%$ of respondents stated that the safety facilities were standard, while $36.6 \%$ stated that they were guaranteed. This condition is related to the type of transportation they use and personal awareness of safety equipment.

2. Availability of equipment at STIP for emergency conditions
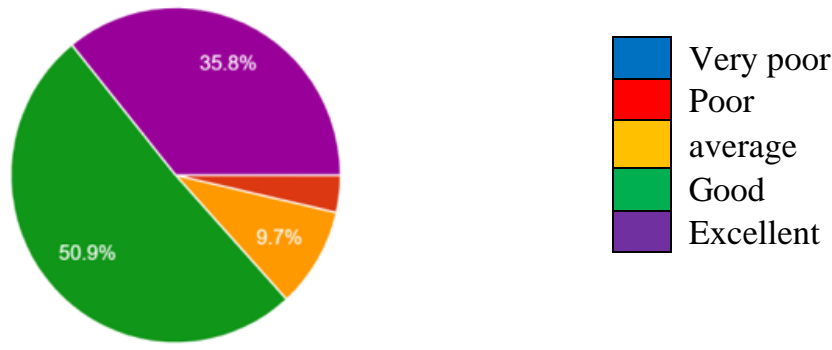

Figure 12 Safety Facility Diagram

This paper is presented in The $4^{\text {th }}$ International Conference on Maritime Education and Training 
Figure 12 shows the availability of safety equipment in the STIP environment. Several Instructions posted around STIP, especially the service area, can make it easier for participants to find something. As many as $50.9 \%$ of respondents stated that the existence and function of the tools and safety instructions for them were apparent, even as many as $35.8 \%$ of respondents stated that it was evident.

3. Availability of information and health facilities such as health rooms, first aid kits, and health workers at STIP

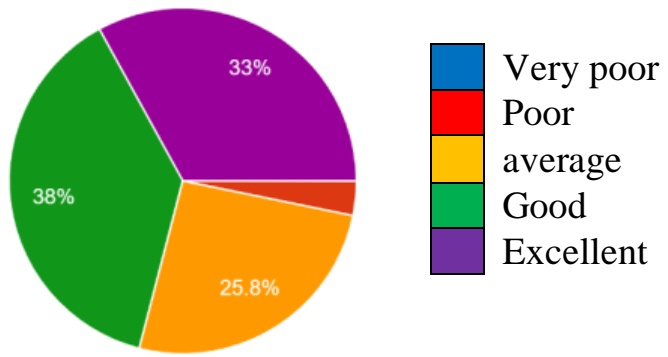

Figure 13 Diagram of Information Availability and Health Facilities

Figure 13 shows the availability of information and health facilities at STIP related to services for seafarers. As many as $38 \%$ of respondents stated that the availability of information was adequate.

B. On time service

1. Queue in waiting room according to Waiting Time

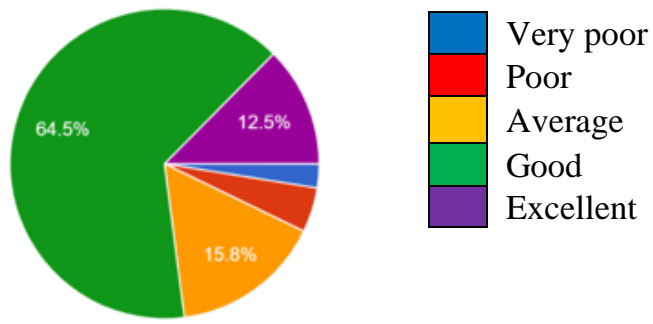

Figure 14. Suitability Diagram of Queues in the Waiting Room

Figure 14 shows the queues' suitability in the waiting room with the waiting time at the service counter. It was found that as many as $64.5 \%$ of respondents stated that they were appropriate, as many as $15.8 \%$, and as many as $12.5 \%$ stated that they were very suitable.

2. Quick revalidation registration service process
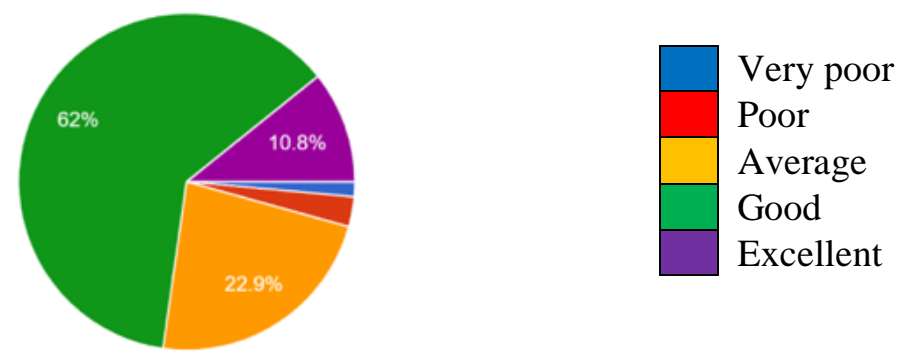

Figure 15 Diagram of the Speed of the Registration Revalidation Process at STIP

Figure 15 shows the speed of the revalidation registration process at STIP, and the results show that $62 \%$ of respondents stated that the revalidation service was carried

This paper is presented in The $4^{\text {th }}$ International Conference on Maritime Education and Training 172 
out quickly. As many as $22.9 \%$ of respondents stated that the revalidation service was typically carried out, only $10.8 \%$ stated that the revalidation service was high-speed.

3. Fast revalidation payment process
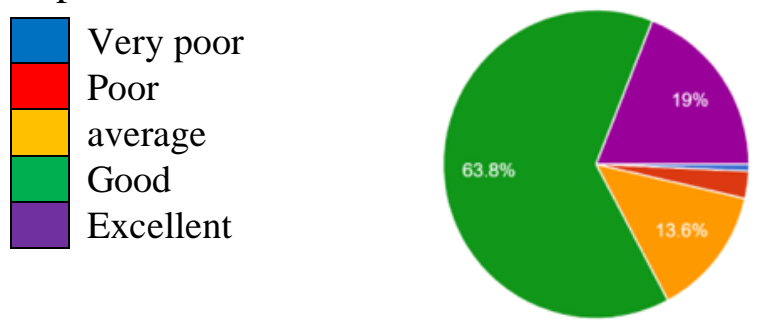

Figure 16 shows the revalidation payment process at STIP, and the results show that $63.8 \%$ of respondents stated that the revalidation payment process was carried out quickly. As many as $13.6 \%$ of respondents stated that the revalidation service was typically carried out, $19 \%$ stated that the revalidation service was highspeed.

4. The health examination process takes place on time
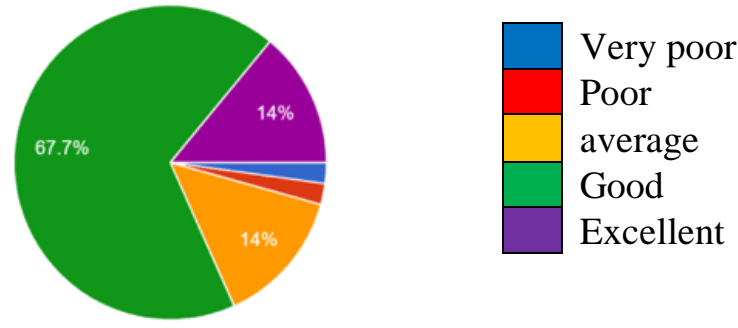

Figure 17 Timeliness of Health Checks Diagram

Figure 17 shows the health examination process at STIP, and the results show that $67.7 \%$ of respondents stated that the health examination process took place on time. The same condition occurred for the health examination process, which was very punctual and ordinary, namely as much as $14 \%$.

5. The verification process

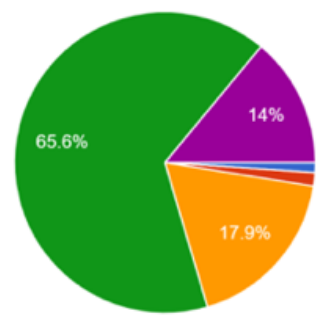
Very poor
Poor
Average
Good
Excellent

Figure 18 Verification Process Diagram

Figure 18 shows the speed process in the verification process at STIP, and the results show that $65.5 \%$ of respondents stated that the verification process was fast. As many as $17.9 \%$ said it was expected, $14 \%$ said the verification process was speedy. 


\section{Service Accuracy}

1. Availability of service flow information revalidation
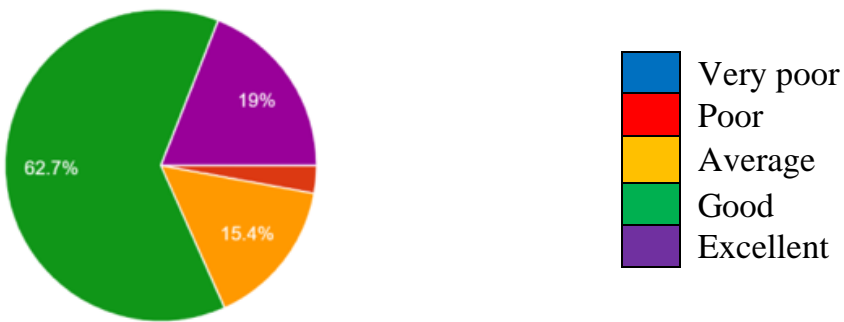

Figure 19 Diagram of the Availability of Revalidation Service Flow Information

Figure 19 shows the Availability of Service Flow Information Revalidation of the ease of service information at STIP. The results show that $62.7 \%$ of respondents said it was easy to get service information at STIP, $19 \%$ of respondents said it was straightforward, and $15.4 \%$ said it was normal.

2. Availability of information on revalidation service prices and implementation time
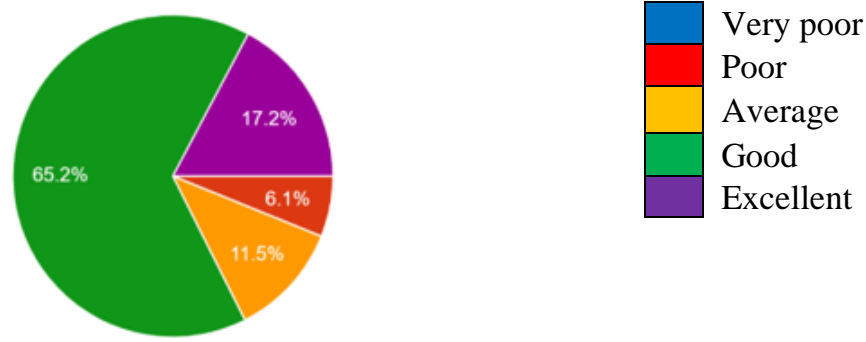

Figure 20 Diagram of Price Information and Implementation Time of BST Revalidation

Figure 20 shows the Availability of Price Information and Implementation Time for BST Revalidation. As much as $65.2 \%$ states there is and is easy to obtain. As many as $17.2 \%$ of respondents stated that the available information was abundant and easy to obtain. Meanwhile, $11.5 \%$ of respondents said it was normal. The information available on STIP is provided online on the website and available at the service counter at STIP.

D. Response to the revalidation plan with long distance assessment

1. Understanding the concept of revalidation by long distance assessment
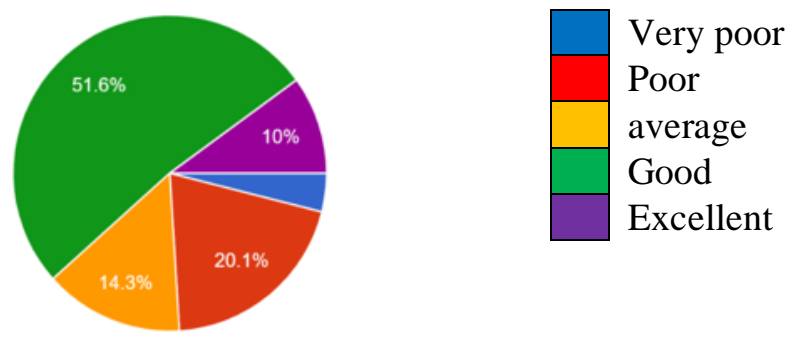

Figure 21 Diagram of understanding the concept of revalidation by long distance assessment

Figure 21 shows the assessment of participants' understanding of the concept of long-distance revalidation. A total of $51.6 \%$ of respondents understand 
the concept of long-distance revalidation, followed by $20.1 \%$ of respondents who do not understand, $14.3 \%$ are ordinary or neutral, $10 \%$ of respondents understand very well, and the rest are respondents who do not understand the concept of revalidation at all. Based on the results of the diagram, it can be seen that most of the training participants understand the concept of long-distance revalidation.

2. Approval if the revalidation is done by online
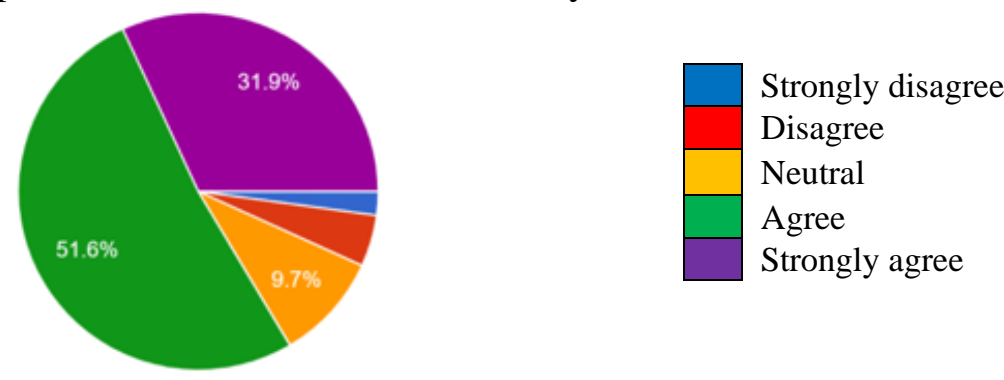

Figure 22.Diagram of the respondent's agreement on Online Revalidation

Figure 22 shows a participant assessment diagram regarding online revalidation, showing $51.6 \%$ of respondents agree to online revalidation, $31.9 \%$ strongly agree, $9.7 \%$ are average or neutral. The rest are followed to disagree and strongly disagree. Based on these results, most respondents agreed to do online revalidation, considering that this can make it easier for participants who want to validate the certificate. However, their position is still on the ship

3. Do you need for long-distance revalidation assessments
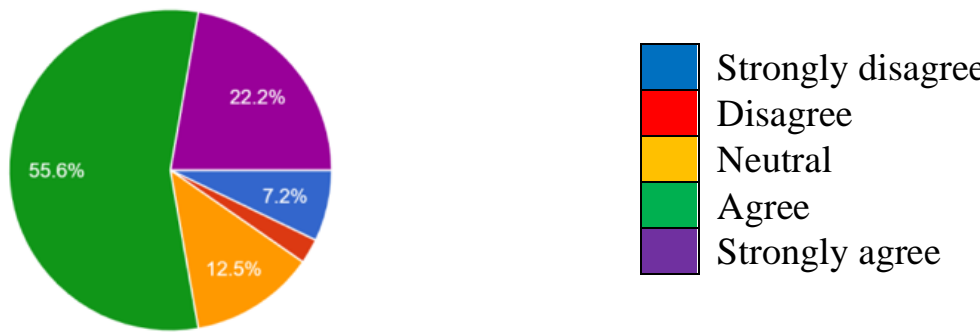

Figure 23.Diagram of the needs of long distance revalidation assessment

In Figure 23, the participant's opinion diagram regarding the long-distance revalidation assessment shows that $55.6 \%$ of respondents felt the need to do a longdistance revalidation assessment, followed by $22.2 \%$ essential, $12.5 \%$ ordinary or neutral, 7.2\% unnecessary, and the rest is less necessary. Based on the results of the diagram, it can be seen that most respondents feel the need to hold a long-distance revalidation assessment.

4. Convenience of implementation of revalidation conducted by long-distance assessment
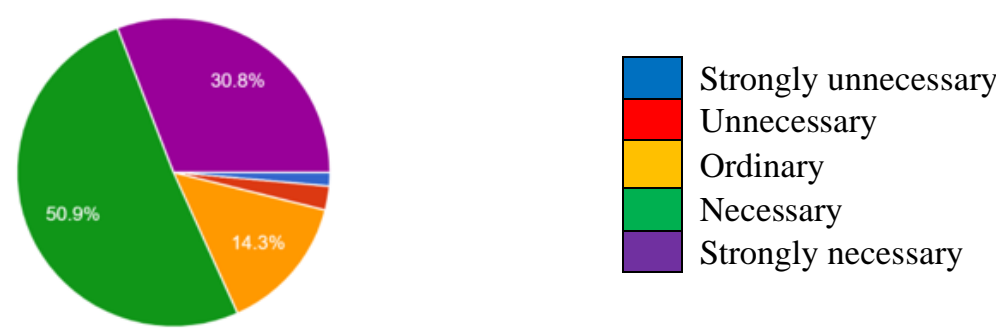

Figure 24 Diagram of the convenience when implementing revalidation with longdistance assessments

This paper is presented in The $4^{\text {th }}$ International Conference on Maritime Education and Training 
In Figure 24, the participant's opinion diagram regarding the long-distance revalidation assessment shows that $50.9 \%$ of respondents felt the need to do a longdistance revalidation assessment, followed by $30.8 \%$ very necessary, $14.3 \%$ ordinary or neutral, $7.2 \%$ unnecessary, and the rest is less necessary. Based on the results of the diagram, it can be seen that most respondents feel the need to hold a long-distance revalidation assessment.

\section{E. Convenience of Technology Access}

1. Internet usage in general
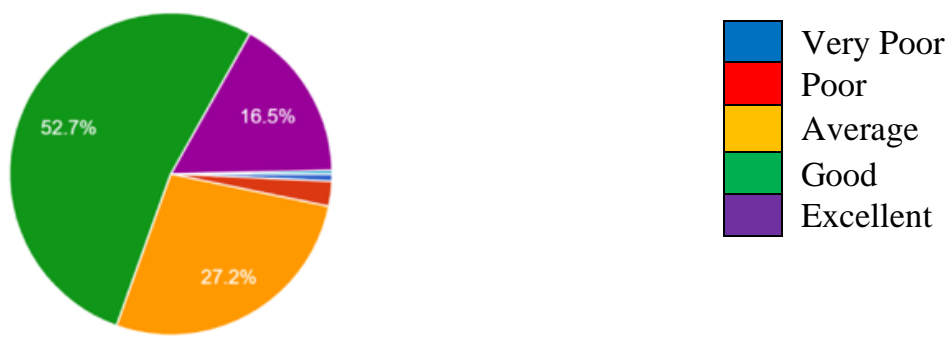

Figure 25 Diagram of understanding the use of the internet in general

Figure 25 diagram of internet use by revalidation participants, based on these results, found that $52.7 \%$ of respondents understood the use of the internet in general, $27.2 \%$ felt normal or neutral, $16.5 \%$ understood internet use, then followed by not understanding and very much do not understand. Based on these results, it can be seen that most participants understand the use of the internet in general.

2. Convenience internet access
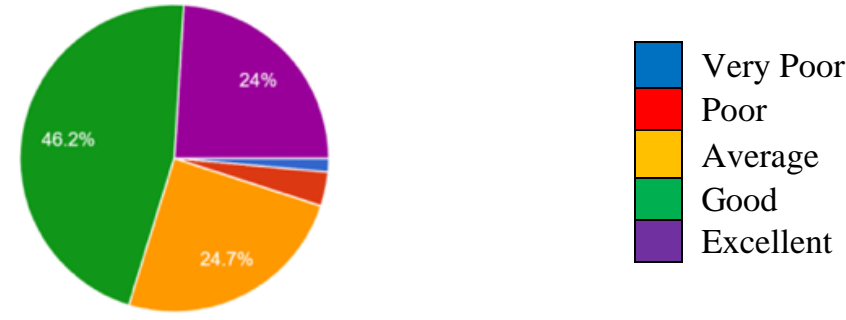

Figure 26 Diagram of respondents' internet access

In Figure 26, the diagram of the ease of finding internet access in the residence of the revalidation participants, it was found that $46.2 \%$ of respondents felt it was easy to get internet access where they lived, $24.7 \%$ felt normal or neutral, $24 \%$ felt very good at getting access internet, then followed severely and was very poor in getting internet access where the participants lived.

3. Convenience internet access when on board

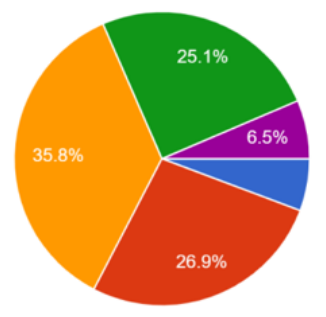

Very Poor

Poor

Average

Good

Excellent

Figure 27 Diagram of respondents' internet access on board

This paper is presented in The $4^{\text {th }}$ International Conference on Maritime Education and Training 
In Figure 27, the diagram of the ease of internet access on board, 35.8\% of respondents feel normal or neutral in getting internet access on board, $26.9 \%$ feel bad in getting internet access on board, followed by $25.1 \%$ feel good, $6.5 \%$ felt very good and the rest very bad. Based on the results of the diagram, it was found that some respondents did not have such easy access to the internet on board considering the conditions on the ships, most of which were far from the mainland, so that internet access became less stable even though there was Wi-Fi on board. 4. Difficulty when operating the google system.
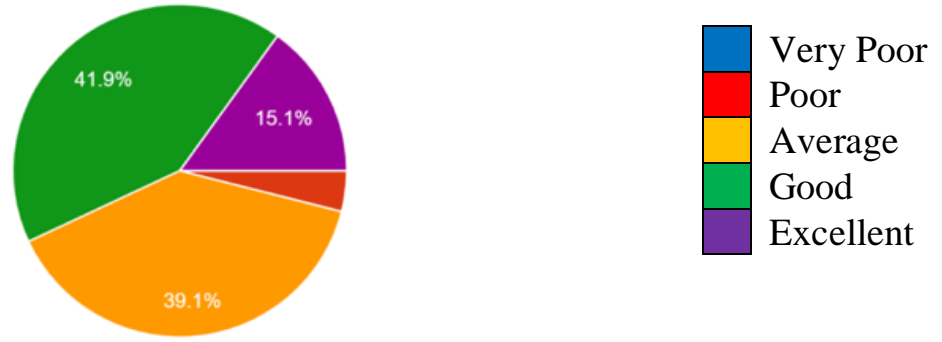

Figure 28 Difficulty diagram operating the google system

Figure 28 of the participant opinion diagram regarding the operation of the Google system found that $41.9 \%$ felt useful in operating the Google system, 39.1\% felt normal or neutral, $15.1 \%$ felt very good, then followed by feeling bad in operating the system Google. Most of the respondents have no problem regarding the operation of the Google system.

\section{Purchase internet packages}
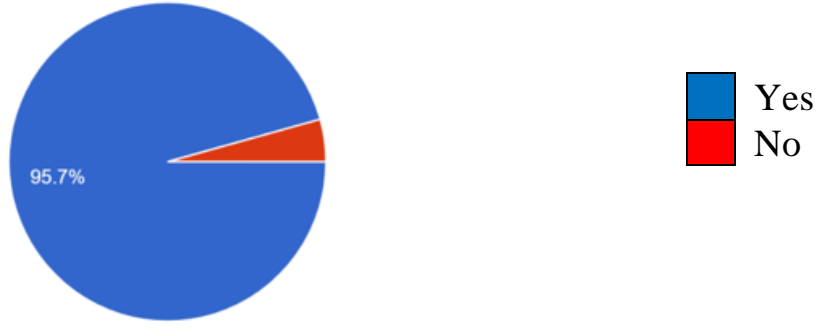

Figure 29 Diagram of internet package purchases by respondents

Figure 29 of the participant diagram related to purchasing Internet packages, based on the diagram, shows that $95.7 \%$ of respondents always buy internet packages, and the remaining $4.3 \%$ do not buy internet packages.

6. Use of Wi-Fi facilities if you want to use the internet

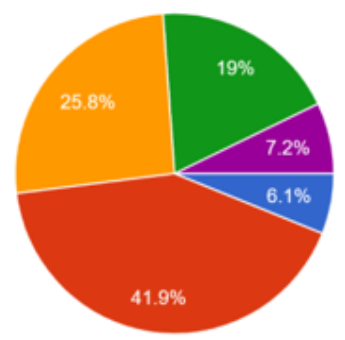

Strongly disagree

Disagree

Neutral

Agree

Strongly agree

Figure $30 \mathrm{Wi}-\mathrm{Fi}$ usage diagram for the Internet

Figure 30 shows the use of Wi-Fi for revalidation participants. It is found 
that $41.9 \%$ of respondents do not rely on Wi-Fi, $25.8 \%$ are regular or neutral, and $19 \%$ rely on Wi-Fi use, $7.2 \%$ rely heavily on upon, and $6.1 \%$ do not rely heavily on. Based on this diagram, most respondents do not rely on Wi-Fi to access the internet.

7. Difficulty operating the internet

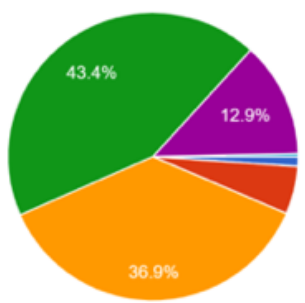

Very Poor

Below average

Average

Above average

Very much to

Figure 31 Diagram of respondents' difficulties in operating the internet

In Figure 31, the diagram is related to the difficulties of operating the internet for revalidation participants. As many as $43.4 \%$ felt it was not difficult to operate the internet, $36.9 \%$ of respondents felt normal or neutral, then $12.9 \%$ of respondents felt it was straightforward and followed by complicated and very fruity.

8. Development of mobile phone technology

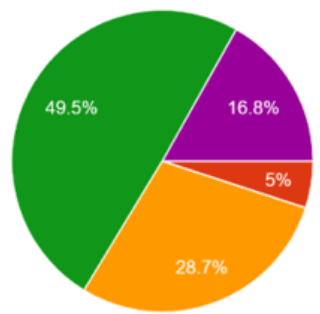

Never

Rarely

Sometime

Most of the time

Always

Figure 32 Diagram of respondents' participation in the development of mobile technology

In Figure 32, the diagram of technological developments followed by participants found that $49.5 \%$ of respondents follow cellphone technology development, then $28.7 \%$ of respondents feel normal or neutral, then $16.8 \%$ of respondents follow, and 5\% do not follow technological developments handphone. Based on these results, most of the respondents/participants of the revalidation followed cellphone technology development.

9. Android type cellphone users

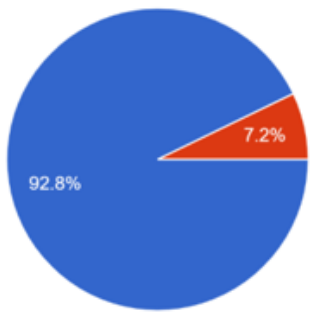

Yes

No

Figure 33 Diagram of the use of Android cellphones by respondents

In Figure 33, the diagram of the use of Android by the revalidation participants, it was found that $92.8 \%$ of participants used cellphones with the 
Android operating system, followed by $7.2 \%$ of respondents who did not use Android.

10. Use of Ios / Apple type mobile phones
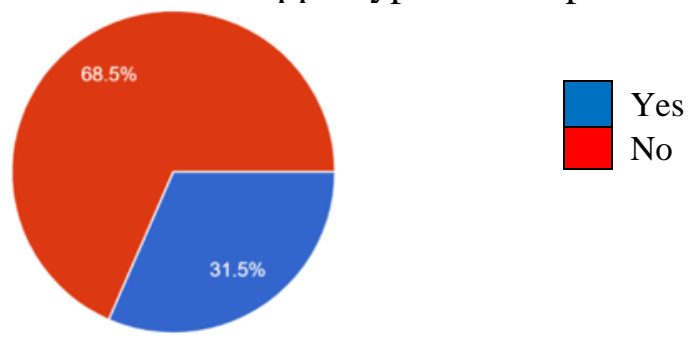

Figure 34 Diagram of the use of IOS / APPLE cellphones

Figure 34, the diagram of the use of iOS / Apple by revalidation participants, found that $68.5 \%$ of participants do not use cellphones with the iOS / Apple operating system and $31.5 \%$ use iOS / Apple.

11. Skype application usage

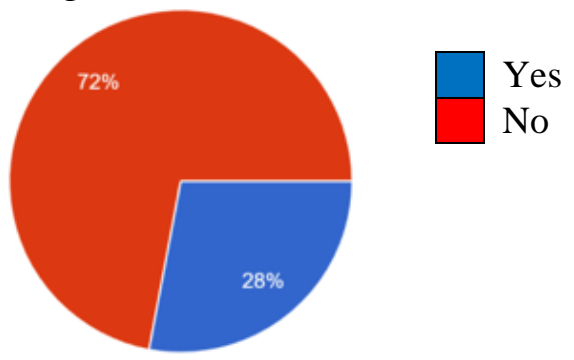

Figure 35 Diagram of the use of the Skype application by Respondents

Figure 35 shows the use of Skype by revalidation participants. Based on these results, it was found that $72 \%$ of respondents did not use the Skype application and followed by $28 \%$ of respondents using the Skype application as a communication medium.

From the data obtained above, we can see that the current STIP services are quite good in terms of service, comfort, availability of information is sufficient. In terms of implementing the online revalidation plan, it was found that $51.6 \%$ of respondents expected online revalidation, and the respondents understood the principles of online revalidation.

The system expected from this online validation model is a system that is easy for users (user-friendly) because most of the Seafarers, in this case, represented by respondents, use mobile phone communication media with the Android operating system.

\subsection{Online Revalidation Registration Model}

Following the development of existing technology and adapted to seafarers' capabilities, the researchers tried to make the online revalidation registration model as easy as possible, without having to complicate users. The online revalidation registration model can be seen through the following flow: 


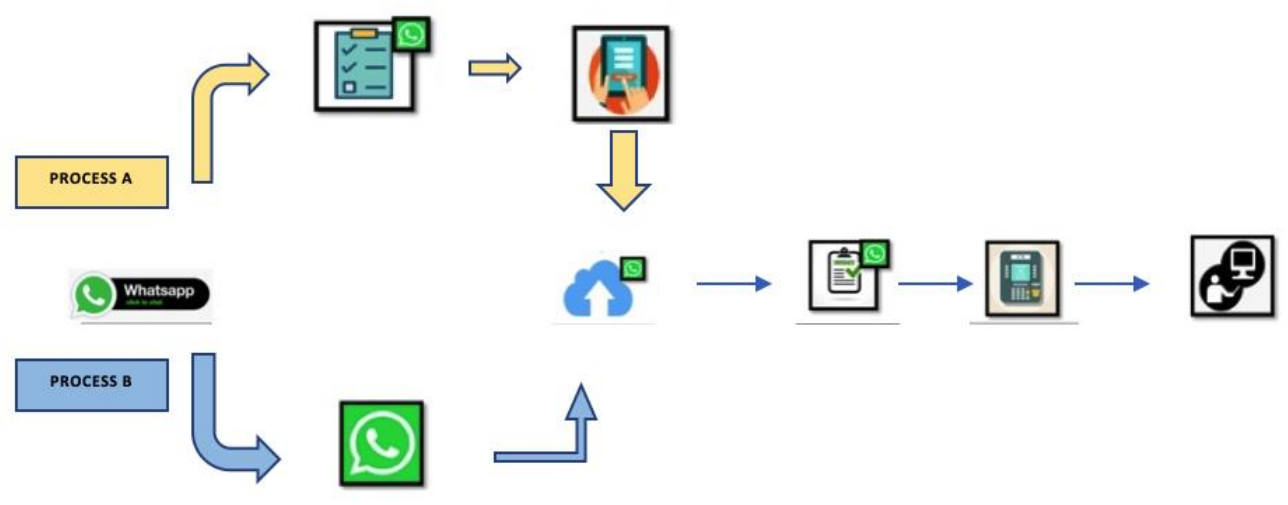

Figure 36 STIP Training Registration Flow

In Figure 36, the education and training registration flow carried out at STIP can be explained as follows:

1) PROCESS A

a. Prospective training participants can register via the STIP whatsapp customer service application

b. After registering via WA, the prospective participant will get a register link which must then be opened by the prospective participant

c. On the link, participants are provided with an application form and other documents that must be filled in.

d. After the form and documents are filled in, they must be uploaded again via WA Customer Service STIP for verification.

e. The CS officer verifies the registration form and documents, if they are appropriate and complete, a Virtual Account number will be issued as the basis for training payments to be paid by prospective training participants.

f. Prospective training participants pay training fees through the bank, and proof of transfer / payment can be sent back to the CS officer.

g. Prospective training participants are informed about the learning schedule to be carried out online using the distance learning method.

2) PROCESS B

a. Prospective training participants contact CS officers using the WA application.

b. Prospective training participants register by providing personal data through the WA STIP customer service

c. CS STIP officers help register prospective training participants via the available registration link.

d. After the form and documents are filled in, the prospective training participants upload back through the WA Customer Service STIP for verification.

e. The CS officer verifies the registration form and documents, if they are appropriate and complete, a Virtual Account number will be issued as the basis for training payments to be paid by prospective training participants.

f. Prospective training participants pay training fees through the bank, and proof of transfer / payment can be sent back to the CS officer.

g. Prospective training participants are informed about the learning schedule to be carried out online using the distance learning method.

With the conditions where seafarers live far from Jakarta, and due to the current

This paper is presented in The $4^{\text {th }}$ International Conference on Maritime Education and Training 
pandemic situation, STIP opens an online registration path that can be accessed by the internet. The registration system is made as easy as possible by opening the link available on the STIP website. The link can be accessed using a cellphone or a computer (personal computer). Training participants only need to upload or upload files/documents for requirements through the system, and then the admin will verify it. After verification is done, participants will get a Virtual account number to make training payments through the Bank. The results/proof of payment can be uploaded via WhatsApp, which is sent to the admin, and finally, the participants will be informed about the online learning schedule.

So simple and easy. Participants do not need to attend to STIP; they need to take advantage of existing technology. To maintain the attached documents' authenticity, participants are required to fill out a statement letter, which must also be sent to the administrator.

\subsection{Online Revalidation Evaluation Model}

E-LEARNING PROCESS FOR REFRESHING AND REVALIDATION

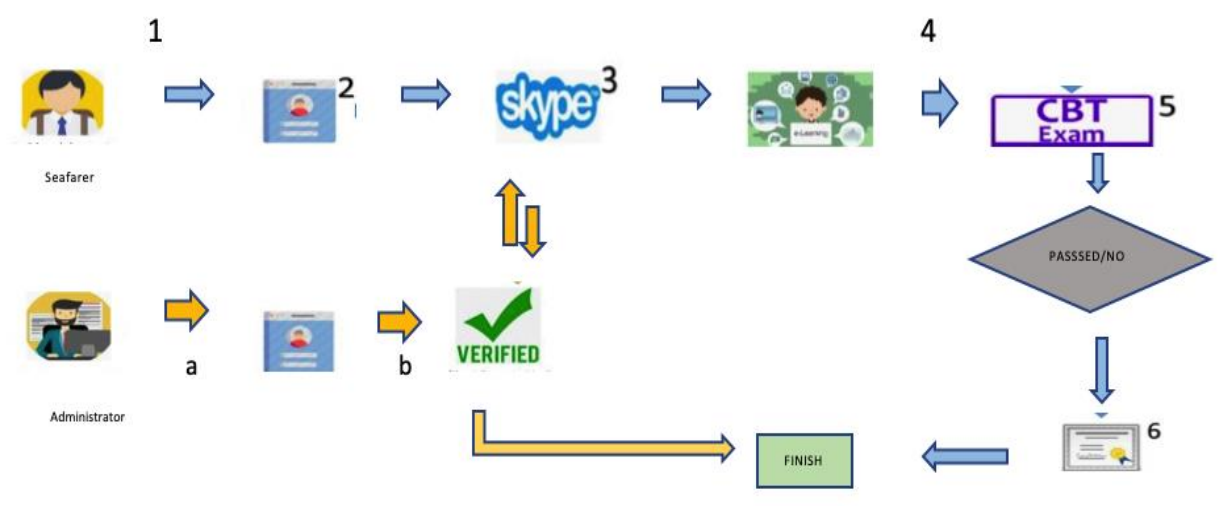

Figure 37 Online Revalidation Evaluation Model

For the online revalidation evaluation model, as seen in Figure 37, the researcher tries to develop from the existing learning system, which is done manually face-toface. The participants still have to do that part but in a different way, as follows:

1) The Participants need to apply for the online registration.

2) Tthe administrator will check as per all the procedures.

3) If they pass all the requirements, they will be given a link and a code to join Skype. Through this method, the Assessor or the administrator will validate the participants' authenticity and originality. Participants also requested to show the identity card (ID Cards) at the same time.

4) The evaluation is made by utilizing the system available on the google form. Once the administrator or the Assessor approves the Participants, participants will be sent a link for filling out the evaluation at the end of the lesson.

5) The link contents are in the form of participant names, the training period, and which mainly contains several questions or questions related to the skills training taken. In this sample test is the BST training (see Figure 38 \& Figure 39).

6) At the end of the session, the Assessor or administrator will check the assessment result then will be approved if they are passed the assessment.

Figure 39 is an example of the initial appearance of the online revalidation

This paper is presented in The $4^{\text {th }}$ International Conference on Maritime Education and Training 181 
evaluation. Participants will see this display and will be asked to fill in the name and training period. This process can be done via cellphone and computer.

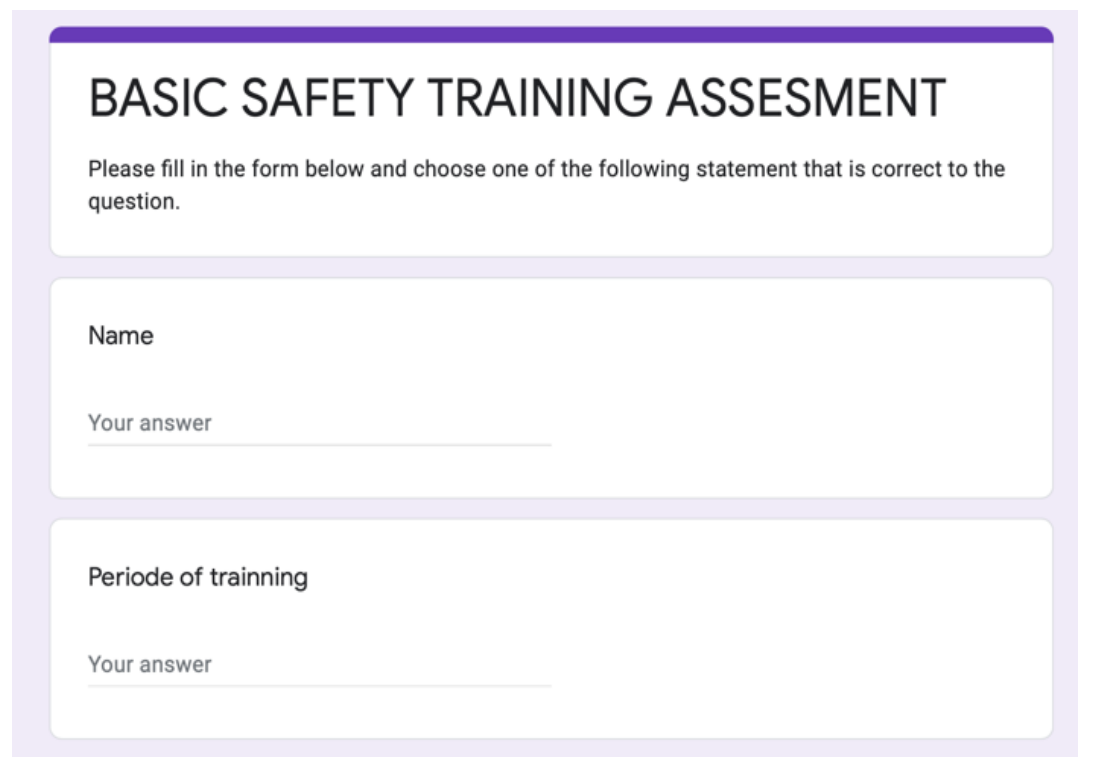

Figure 38 Cover of BST online revalidation assessment

Figure 39 is an example of a display of questions for online revalidation evaluation. Participants can choose the correct answer by selecting / clicking the answer that is considered correct. This link will be directly connected to the training implementer, and the results can be directly checked by Assesor/ administrator through the system. With this system, it certainly makes very easy for Assesors and saving more time. In addition, participants also do not need to come or attend STIP, or do not have to request for signing off only for revalidation.

\section{BASIC SAFETY TRAINING ASSESMENT}

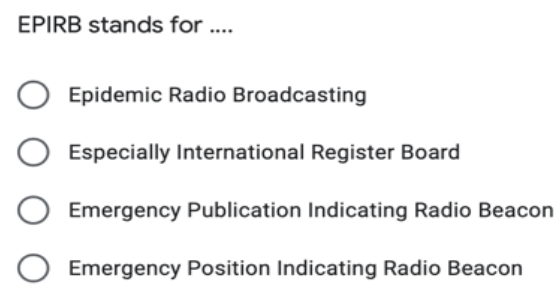

Figure 39 Sample questions of BST revalidasi online 


\section{Conclusion}

Based on the description that the researcher has put forward before, it can be concluded as follows:

1. Implementation of online BST certificate revalidation at STIP can be carried out with due observance of the requirements starting from the registration process, evaluation to the issuance of the revalidation certificate.

2. The legality of a certificate revalidation that is carried out online is the same and legal as a revalidation certificate that is carried out regularly. The entire series of processes is carried out in accordance with applicable Standard of Procedures and does not provide any loopholes for fraudulent acts.

3. It is necessary to make an application based on the official website that summarizes the

features of the research results of the lecturers, especially for research that raises developments in the certification of each seafarer skills training.

The current research only discusses one type of skills training which is expected to provide meaningful input to regulators, especially in the Directorate General of Sea Transportation, Ministry of Transportation. Therefore, researchers try to provide suggestions:

1. There is a need for further discussion regarding the system of procedures for implementing online education and training by applying certain methods according to current developments.

2. Providing materials on Information Technology for all COP'and COC's participants especially in operational level.

3. Providing a sufficient budget to each Training Admnistrator of Education and Training under BPSDM Transportation for the development and improvement of management information systems and information technology so that each Training Admnistrator can prepare to face the industrial revolution 4.0 that can come at any time.

\section{References}

[1] Anomim. 2016. Pengertian Kepuasan Pelanggan dan Kualitas Pelayanan.

[2] Aritonang R.L. 2005. Kepuasan Pelanggan. Gramedia. Jakarta.

[3] Cahyaningrum. 2012. Analisis Kepuasan Konsumen Atau Pelanggan Terhadap Pelayanan Jasa Pos.

[4] Fandy Tjiptono and Gregorius Chandra. 2007. Service, Quality Satisfaction. Andi Ofset. Yogyakarta.

[5] Irawan, H. 2003. Indonesian Customer Satisfaction. PT Gramedia Pustaka Utama. Jakarta.

[6] M. Yamin Jinca. 2011. Transportasi Laut Indonesia, Analisis Sistem dan Studi Kasus. Brilian Internasional, Surabaya.

[7] Salim Abbas. 2004. Manajemen Transportasi. Raja Gravindo Persada. Jakarta.

[8] Sugiyono. 2013. Metode Penelitian Kuantitatif Kualitatif dan R\&D. Alfabeta. Bandung.

[9] Wouter Jacobs. 2015. The Role of Port Infrastructure and Logistics in Global Networks. 